INOBIS: Jurnal Inovasi Bisnis dan Manajemen Indonesia

Volume 1, Nomor 2, Maret 2018

Tegowati; Nenny Syahrenny; Wininatin Khamimah; Mega Arisia Dewi

\title{
Pengaruh Lifestyle, Efek Komunitas dan Fitur Produk terhadap Brand Switching Warung Internet ke Wifi ID Corner (Studi pada Wifi Id Corner di Denpasar)
}

\author{
I Putu Wimahayana Adnyana ${ }^{1}$ \\ Ni Ketut Seminari ${ }^{2}$ \\ 1.2 Jurusan Manajemen Fakultas Ekonomi dan Bisnis \\ Universitas Udayana, Bali, Indonesia \\ 1e-mail: wimahayana_39@yahoo.com / 082146587215 \\ 2e-mail : ketutseminari@yahoo.com /08123952839
}

\begin{abstract}
Abstrak
Konsumen sebelumnya menggunakan warung internet untuk memenuhi kebutuhannya dalam hal pencarian informasi di internet. Perkembangan zaman dan teknologi ke arah yang lebih modern, berdampak munculnya banyak teknologi baru yang bergerak di bidang telekomunikasi dan informasi seperti contoh teknologi Wi-Fi. Penelitian ini bertujuan untuk mengetahui pengaruh lifestyle, efek komunitas serta fitur produk kepada brand switching. Penelitian di lakukan di Kota Denpasar dengan pelanggan Wifi id corner sebagai subjek penelitian. Ukuran sampel yang digunakan berjumlah 102 orang dengan perhitungan 17 x $6=102$ (jumlah indikator dikali 5 sampai 10). Penentuan sampel menggunakan teknik non-probability sampling dengan teknik purposive sampling. Pengumpulan data dilakukan dengan menyebarkan kuesioner dan wawancara. Skala Likert digunakan untuk mengukur 17 indikator dari empat variabel penelitian. Regresi linier berganda adalah teknik analisis yang digunakan untuk mengolah data yang telah dikumpulkan. Hasil penelitian ini menunjukkan bahwa masing-masing variabel yang diuji telah valid dan reliabel serta uji asumsi klasik menyatakan model penelitian sudah layak untuk diujikan. Hail penelitian menunjukkan bahwa eluruh variabel bebas (lifestyle, efek komunitas dan fitur produk) berpengaruh positif dan signifikan terhadap keputusan brand switching konsumen wifi id corner di Denpasar.
\end{abstract}

Kata kunci: Lifestyle, efek komunitas, fitur produk, brand switching

\section{Pendahuluan}

Perkembangan teknologi komunikasi saat ini sangat pesat, dengan dibuktikan oleh banyaknya inovasi mulai yang sederhana maupun lebih kompleks. Salah satunya adalah internet. Internet (Interconnected Network) ialah sistem jaringan komunikasi global yang menghubungkan komputer-komputer hingga jaringan-jaringan komputer dalam sebuah sistem jaringan komputer mencakup seluruh dunia. Meningkatnya perkembangan di bidang teknologi, telekomunikasi dan komputer berdampak pada kemajuan teknologi internet (Prihastono 2010).

Indonesia memiliki 63 juta pengguna internet dari 245,5 juta populasi penduduk Indonesia pada tahun 2012 serta penggunanya meningkat setiap tahun, hal ini dapat di lihat dari Tabel 1. Peningkatan penggunaan layanan internet mendorong munculnya suatu tuntutan pelayanan internet melebihi dari apa yang bisa diperoleh di dunia nyata (Wibowo 2013). Pada bisnis, penggunaan internet berubah dari fungsi dari alat untuk pertukaran informasi secara 
INOBIS: Jurnal Inovasi Bisnis dan Manajemen Indonesia

Volume 1, Nomor 2, Maret 2018

Tegowati; Nenny Syahrenny; Wininatin Khamimah; Mega Arisia Dewi

elektronikmenjadi aplikasi strategi bisnis antaralain untuk pelayanan, pemasaran, dan penjualan kepada pelanggan. Pemasaran di internet bisa menembus berbagai macam rintangan misalahnya batas bangsa, dan tanpa aturan-aturan yang baku sedangkan pemasaran konvensional, barang mengalir dalam partai-partai besar, melalui pelabuhan laut, menggunakan kontainer, distributor, lembaga penjamin, importir, dan lembaga bank. Lebih banyak pihak yang terlibat dalam pemasaran konvensional dibandingkan pemasaran lewat internet. Pemasaran di internet sama dengan direct marketing (pemasaran langsung) yaitu konsumen berhubungan langsung dengan penjual, walaupun berada di luar negeri (Yuliana 2010).

Tabel 1 Jumlah dan Penetrasi Pengguna Internet di Indoneisa, Tahun 2011 - 2015

\begin{tabular}{cccc}
\hline Tahun & $\begin{array}{c}\text { Jumlah Penduduk } \\
\text { (Juta Jiwa) }\end{array}$ & $\begin{array}{c}\text { Jumlah Pengguna } \\
\text { Internet } \\
\text { (Juta Jiwa) }\end{array}$ & $\begin{array}{c}\text { Penetrasi } \\
\text { Pengguna Internet } \\
\text { (Dalam } \\
\text { Persentase) }\end{array}$ \\
\hline 2011 & 242,0 & 55,0 & $22,7 \%$ \\
2012 & 245,5 & 63,0 & $25,7 \%$ \\
2013 & 248,9 & 71,2 & $28,6 \%$ \\
2014 & 252,4 & 88,1 & $34,9 \%$ \\
2015 & 256,2 & 132,7 & $51,8 \%$ \\
\hline Sumber: Survei APJII (Asosiasi Penyelenggara Jasa Internet Indonesia)
\end{tabular}

Tuntutan persaingan dalam pengelolaan kegiatan usaha dari lingkup organisasi bisnis pada masa mendatang dipastikan akan semakin ketat. Perkembangan inilah yang mendorong semua sektor usaha untuk menambahkan jasa atau pelayanan pada setiap produk yang ditawarkannya, tidak peduli bergerak dibidang apa organisasi bisnis yang mereka jalani. Dalam kehidupan masyarakat modern, pola hidup masyarakat dan segala aktivitasnya secara tidak langsung akan dipengaruhi oleh globalisasi. Cara perusahaan dalam memanfaatkan informasi pun telah berubah akibat dari persaingan global (Krisnadewi 2010). Komunikasi secara global serta kebutuhan informasi yang semakin capat, menjadikan perusahaan-perusahaan melakukan persaingan yang kompetitif dalam rangka menguasai pasar.

Lifestyle memberikan peranan penting terhadap perilaku konsumen dalam melakukan suatu transaksi ataupun pembelian. Dalam segmentasi pasar, lifestyle memiliki peranan penting didalamnya, dimana perusahaan diharuskan untuk menyadari bahwa mustahil untuk melayani seluruh pelanggan yang ada di pasar. Pola kehidupan seseorang dapat ditunjukan dari lifestyle orang yang bersangkutan dimana tercermin dalam kegiatan, minat dan pendapatnya. Produsen diharapkan dapat memahami konsep lifestyle tersebut dengan cermat sehingga dapat membantu untuk memahami nilai-nilai konsumen yang terus beubah dan bagaimana nilai-nilai tersebut mempengaruhi perilaku konsumen.

Selain lifestyle, ada faktor lain yang menjadi pertimbangan konsumen memenuhi kebutuhannya yaitu adalah efek komunitas. Efek komunitas juga berpengaruh besar dalam kepemilikan suatu produk oleh masyarakat. Adanya komunitas di sekitar kita menjadikan suatu fenomena menarik untuk diamati karena memiliki dampak bagi dunia pemasaran. Komunitas ini dijadikan sebagai unit spasial atau politik dari suatu organisasi sosial yang dapat memberikan individu perasaan kebersamaan atau perasaan saling memiliki (sense of belonging) oleh pemasar. Perasaan kebersamaan ini diantaranya didasarkan oleh kebersamaan daerah tempat tinggal seperti 
INOBIS: Jurnal Inovasi Bisnis dan Manajemen Indonesia

Volume 1, Nomor 2, Maret 2018

Tegowati; Nenny Syahrenny; Wininatin Khamimah; Mega Arisia Dewi

kota tertentu atau hubungan ketetanggaan serta perasaan saling memiliki identitas yang sama (Mardiastika 2012).

Komunitas semakin memiliki peran penting dalam dunia pemasaran. Ikatan emosional antar anggota komunitas memberikan dampak yang sangat signifikan bagi sebuah merek, baik itu dampak negatif ataupun positif (Susanto 2011). Selain itu pengaruh komunitas semakin dominan terhadap preferensi produk atau merek yang dipilih dan digunakan oleh para anggotanya, sehingga konsumen dalam komunitas menjadi juru bicara atau iklan yang efektif bagi perusahaan. Perubahan dalam sikap dan perilaku individu dipengaruhi oleh kelompok sebaya yang menyebabkan terjadinya kebutuhan untuk diterima oleh kelompok sebaya. Adanya kebutuhan untuk diterima dalam kelompok sebaya menyebabkan individu melakukan perubahan dalam sikap dan perilaku sesuai dengan perilaku anggota kelompok teman sebaya (Ramadhani 2013). Oleh karena itu, apabila individu dalam suatu kelompok sebayanya menggunakan produk jenis tertentu, kecenderungan individu untuk menggunakan produk sejenis atau jenis yang sama akan lebih besar.

Lifestyle dan efek komunitas merupakan dua dari banyak faktor yang mempengaruhi konsumen dalam memenuhi kebutuhannya. Terdapat faktor lainnya yang memberikan pengaruh konsumen dalam keputusan pemenuhan kebutuhan baik produk ataupun jasa yaitu fitur produk. Menurut (Alana, dkk. 2013), fitur produk merupakan karakterisktik atau fitur yang mungkin dimiliki atau tidak dimiliki oleh objek. Berbagai fitur yang serupa dapat dilihat berbeda oleh konsumen dari perbandingan fitur di dalamnya, yaitu perbandingan kelengkapan fitur, kecanggihan fitur atau keistimewaan yang ditonjolkan dari satu fitur di suatu produk dibandingkan produk lainnya.

Berbagai fitur produk yang ditawarkan oleh produsen, menyebabkan konsumen akan semakin terpuaskan dengan produk-produk yang sesuai dengan kebutuhannya guna mendiferensiasi produk sejenis yang dihasilkan oleh perusahaan. Agar konsumen dapat memilih produk tersebut, maka diperlukan suatu alat yang menjadi nilai tambah, yaitu dengan menggunakan fitur yang terdapat pada produk tersebut (Hamidah dan Anita, 2013). Demikian juga halnya dengan keputusan konsumen untuk memenuhi kebutuhannya terutama dalam hal teknologi informasi terutama internet. Internet saat ini sudah menjadi bagian dari gaya hidup (lifestyle) masyarakat dimana kepemilikannya tidak terbatas yang artinya semua orang bisa menggunakannya. Konsumen sebelumnya menggunakan warung internet untuk memenuhi kebutuhannya dalam hal pencarian informasi di internet. Warung internet atau yang biasa disingkat warnet merupakan suatu unit organisasi bisnis milik swasta yang berorientasi pada laba dan bergerak dalam bidang pelayanan jasa telekomunikasi dan informasi.

Kota Denpasar memiliki 172 warung internet yang tersebar di empat kecamatan (ppid.denpasarkota.go.id/files/resource/data-warnet.pdf diakses pada tanggal 6 Pebruari 2018). Tabel 2 menunjukkan beberapa data warung internet di Kota Denpasar.

Tabel 2 Data Warung Internet Kota Denpasar Tahum 2011

\begin{tabular}{llll}
\hline No & Nama Warnet & \multicolumn{1}{c}{ Alamat } & \multicolumn{1}{c}{ Kecamatan } \\
\hline 1 & Point. Net & Jl Wr. Supratman No. 26 & Denpasar Timur \\
2 & Sinom Net & Jl Kecubung No 84 & Denpasar Timur \\
3 & Speedol Net & Jl Nusakambangan No 103 & Denpasar Barat \\
4 & Spykee Net & Jl Pulau Serangan & Denpasar Barat \\
5 & Qita Net & Jl Subur No 120 A & Denpasar Barat
\end{tabular}


INOBIS: Jurnal Inovasi Bisnis dan Manajemen Indonesia

Volume 1, Nomor 2, Maret 2018

Tegowati; Nenny Syahrenny; Wininatin Khamimah; Mega Arisia Dewi

\begin{tabular}{llll}
6 & Azzam Net & J1 A Yani Utara Denpasar & Denpasar Utara \\
7 & Infinity Net & J1 Kecubung & Denpasar Utara \\
8 & Swan Internet & J1 Gelogor Carik Pemogan & Denpasar Selatan \\
9 & Jerry Net & J1 Waturenggong & Denpasar Selatan \\
10 & Game Online & J1 Bedugul & Denpasar Selatan \\
\hline
\end{tabular}

Sumber: ppid.denpasarkota.go.id

Tingginya kebutuhan masyarakat terhadap akses data di Bali menjadikan Kota Denpasar tidak hanya dipenuhi dengan akses mobile broadband melalui gadget saja, tetapi juga sudah pada pemenuhan foxed broadband melalui wifi.id corner yang tersebar di 260 lokasi di Denpasar. Meningkatnya kebutuhan masyarakat terhadap akses internet berkecepatan tinggi membuat pihak Telkom memperbanyak jumlah lokasi Wifi Id Corner dan memperluas tempat agar bisa menampung lebih banyak pelanggan, yaitu hingga 200 orang. Pembangunan Wifi Id Corner biasanya mengikuti pengguna yang ada, yakni tempat-tempat berkumpulnya komunitas pengguna internet.

Seiring perkembangan zaman, dengan berkembangnya teknologi ke arah yang lebih modern, mengakibatkan munculnya banyak teknologi-teknologi baru yang bergerak di bidang telekomunikasi dan informasi seperti contoh teknologi Wi-Fi. Banyaknya faktor-faktor yang mempengaruhi keputusan konsumen dalam penggunaan internet seperti perubahan gaya hidup (lifestyle), pengaruh orang lain dan semakin menarik dan banyaknya fitur yang ditawarkan penyedia jasa layanan internet serta perubahan selera konsumen, maka tidak jarang dalam kurun waktu singkat seorang pengguna berganti merek dalam hal ini tempat ber-internet dari warung internet ke fasilitas Wi-Fi salah satunya yang populer saat ini adalah Wi-Fi Id Corner. (Firdaus dan Rahardjo 2015) mengatakan bahwa variasi merek produk yang ditawarkan kepada konsumen membuat kosumen memiliki kesempatan untuk beralih dari satu merek ke merek lainnya, hal yang dikenal sebagai perilaku perpindahan merek (brand switching).

Berdasarkan latar belakang masalah yang telah diuraikan, maka yang menjadi rumusan masalah dari penelitian ini adalah pengaruh dari lifestyle terhadap brand switching warung internet ke wi-fi corner di Kota Denpasar, pengaruh efek komunitas terhadap brand switching warung internet ke wi-fi corner di Kota Denpasar dan pengaruh fitur produk terhadap brand switching warung internet ke wi-fi corner di Kota Denpasar.

\section{Landasan Teori dan Pengembangan Hipotesis}

Gaya hidup menggambarkan seluruh pola seseorang dalam beraksi dan berinteraksi di dunia. Dengan berubahnya gaya hidup, dapat berdampak pada keputusan konsumen untuk beralih merek baik merek lokal maupun internasional (Saeed et al. 2014). Li et al. dalam (Rapala 2014) mengatakan bahwa Istilah 'gaya hidup' berasal dari bidang psikologi dan mengacu pada aspek perilaku sehari-hari yang berorientasi pada orang sehingga dengan beragamnya perilaku seharihari tersebut tidak menutup kemungkinan seseorang untuk melakukan perilaku brand switching. Selain itu, dengan munculnya teknologi terbaru mengakibatkan perubahan gaya hidup dan tentunya berdampak terhadap perilaku brand switching seseorang. Berdasarkan rumusan masalah dan hasil penelitian terdahulu serta teori dan konsep yang telah dikemukakan, maka disusun hipotesis sebagai berikut. 
INOBIS: Jurnal Inovasi Bisnis dan Manajemen Indonesia

Volume 1, Nomor 2, Maret 2018

\section{Tegowati; Nenny Syahrenny; Wininatin Khamimah; Mega Arisia Dewi}

H1: Lifestyle berpengaruh positif dan signifikan terhadap brand switching warung internet ke wifi id corner di Kota Denpasar.

Masyarakat semakin mendasarkan perilaku konsumtif dengan identitas sosial mereka dan menghubungkan merek yang dikonsumsi dengan identitas mereka sehingga perilaku beralih merek tidak dapat dihindari, (Wirtz et al 2013). Menurut (Syahyuti 2003), komunitas adalah sekelompok orang yang hidup bersama pada lokasi yang sama, sehingga mereka telah berkembang menjadi sebuah kelompok hidup (group lives) yang diikat oleh kesamaan kepentingan (common interes) yang berakibat pada rentannya perilaku brand switching. Efek komunitas (community effect) atau sering disebut dengan Brandwagon effect (kawanan insting). (Kertajaya 2010) juga berpendapat, efek komunitas adalah pengaruh sekelompok orang yang saling peduli satu sama lain lebih dari yang seharusnya, di mana dalam sebuah komunitas terjadi relasi pribadi yang erat antar para anggota komunitas tersebut karena adanya kesamaan interest atau values. Ini terlihat dari kecenderungan individu untuk selalu menyamakan perilakunya dengan kelompok acuan sehingga dapat terhindar dari celaan maupun keterasingan. Berdasarkan rumusan masalah dan hasil penelitian terdahulu serta teori dan konsep yang telah dikemukakan, maka disusun hipotesis sebagai berikut.

H2: Efek komunitas berpengaruh positif dan signifikan terhadap brand switching warung internet ke wifi id corner di Kota Denpasar.

Menurut Wulandari (Marbun dkk. 2016) fitur adalah aspek performansi yang berguna untuk menambah fungsi dasar, berkaitan dengan pilihan-pilihan produk dan pengembangannya. Fitur produk adalah apa yang dinyatakan pelanggan mengenai perincian produk seperti keistimewaan, desain, dan kualitas (Usmara 2003:120). Banyak aspek dari fitur produk yang mempertimbangkan penambahan pada teknologi khusus. Hal ini mencakup bentuk fisik produk atau desain, tingkat kualitas, ketahanan, dampak pada lingkungan, dan kemudahan saat digunakan. (Carpenter 2012) juga berpendapat bahwa persaingan antara bentuk dan fitur produk dewasa ini mengakibatkan konsumen mudah untuk beralih merek. Berdasarkan rumusan masalah dan hasil penelitian terdahulu serta teori dan konsep yang telah dikemukakan, maka disusun hipotesis sebagai berikut.

H3: Fitur Produk berpengaruh positif dan signifikan terhadap brand switching warung internet ke wifi id corner di Kota Denpasar.

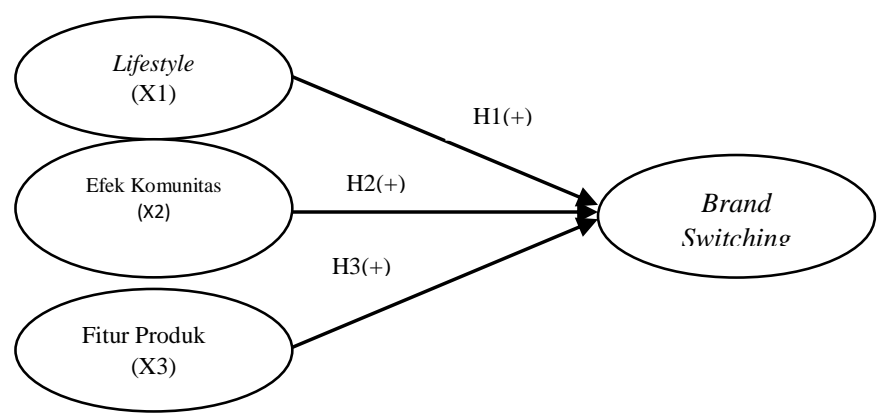

Gambar 1. Model Konseptual Penelitian

Sumber: Data diolah, 2018 
INOBIS: Jurnal Inovasi Bisnis dan Manajemen Indonesia

Volume 1, Nomor 2, Maret 2018

Tegowati; Nenny Syahrenny; Wininatin Khamimah; Mega Arisia Dewi

\section{Metode Penelitian}

Tipe penelitian yang digunakan dalam penelitian ini adalah penelitian explanatory research atau tipe penelitian penjelasan yaitu penelitian yang berusaha untuk menjelaskan pengaruh variabel bebas terhadap variabel terikat. Lokasi penelitian ini di Kota Denpasar dengan pertimbangan bahwa penguna internet terbanyak di Bali berada di Kota Denpasar yaitu sebanyak 291.000 jiwa (Kominfo 2013) serta ruang lingkup yang terdapat pada penelitian ini adalah hanya pada brand switching, lifestyle, fitur produk dan efek komunitas.

Obyek penelitian ini adalah tentang pengaruh dari lifestyle, efek komunitas dan fitur produk terhadap brand switching. Subjek penelitian ini adalah masyarakat pengguna internet di Kota Denpasar yang beralih dari warung internet ke Wifi id corner. Variabel independen dalam penelitian ini adalah lifestyle (X1), efek komunitas (X2) dan fitur produk (X3) sedangkan variabel dependennya adalah brand switching (Y).

Populasi dalam penelitian ini adalah seluruh pelanggan Wifi id corner di Denpasar. Metode pengambilan sampel yang digunakan dalam penelitian ini non-probability sampling dengan teknik purposive sampling yaitu teknik pengambilan sampel yang tidak memberi kesempatan/peluang yang sama bagi setiap unsur atau anggota populasi untuk dipilih menjadi sampel (Rahyuda dkk. 2004). Purposive sampling adalah teknik penentuan sampel dengan pertimbangan tertentu. Pertimbangan kriteria yang digunakan dalam memilih responden adalah pendidikan minimal responden SMA, karena dengan pertimbangan tersebut responden dianggap mampu memahami isi kuesioner serta pelanggan wifi id corner yang sudah melakukan brand switching dari warung internet. Untuk memperoleh hasil dari kuisioner yang telah disebar, diperlukan jumlah sampel responden yang diambil yang ditentukan paling sedikit 5-10 kali jumlah variabel yang akan diteliti. Karena jumlah indikator dalam penelitian ini berjumlah 17 indikator, maka jumlah sampel yang akan diteliti dalam penelitian ini berjumlah sebanyak 102 responden dengan pertimbangan bahwa ukuran dari sampel ini merupakan 5 sampai 10 kali dari jumlah indikator yang digunakan dalam penelitian $(6 \times 17=102)$.

Metode pengumpulan data yang digunakan dalam penelitian ini dengan cara wawancara dan kuesioner. Kuesioner didesain dengan mengacu pada instrumen pengukuran data yang telah teruji den memiliki kredibilitas memadai seperti instrument lifestyle, efek komunitas, fitur produk dan brand switching serta penilaiannya menggunakan skala likert. Sebelum instrument penelitian digunakan untuk mengumpulkan data perlu dilakukan pengujian validitas dan reliabilitas. Sumber primer data penelitian ini antara lain adalah data yang diperoleh melalui kuisioner yang telah disebarkan kepada responden mengenai pengaruh lifestyle, efek komunitas dan fitur produk terhadap brand switching. Sedangkan sumber sekunder data penelitian ini adalah data-data dari hasil penelitian sebelumnya, seperti: penelitian yang telah dilakukan oleh peneliti sebelumnya, artikel dan yang lainnya.

Teknik analisis data yang digunakan untuk memecahkan permasalahan dalam penelitian ini adalah teknik analisis kuantitatif yaitu analisis regresi linear berganda. Untuk regresi yang variabel independennya terdiri atas dua atau lebih, regresinya diebut juga dengan regresi berganda. Persamaan regresi dalam penelitian ini adalah untuk mengetahui seberapa besar pengaruh variabel independen atau bebas yatitu lifestyle (X1), efek komunitas (X2), fitur produk (X3) terhadap variabel terikat (dependen variable) brand switching (Y). Rumus matematis dari regresi berganda yang digunakan dalam penelitian ini adalah. 
INOBIS: Jurnal Inovasi Bisnis dan Manajemen Indonesia

Volume 1, Nomor 2, Maret 2018

Tegowati; Nenny Syahrenny; Wininatin Khamimah; Mega Arisia Dewi

Keterangan.

$$
\mathrm{Y}=\alpha+\beta_{1} \mathbf{X}_{1}+\beta_{2} \mathbf{X}_{2}+\beta_{3} X_{3}+e
$$

$$
\begin{aligned}
& \mathrm{X}_{1} \quad=\text { Lifestyle } \\
& \mathrm{X}_{2} \quad=\text { Efek Komunitas } \\
& \mathrm{X}_{3} \quad=\text { Fitur Produk } \\
& \mathrm{Y}=\text { Brand Switching } \\
& \beta_{1}, \beta_{1}, \beta_{1} \quad=\text { Koefisian regresi dari masing-masing variable } \\
& \alpha \quad=\text { Konstanta }
\end{aligned}
$$

Analisa data yang digunakan dalam penelitian ini adalah analisa model regresi, maka untuk menentukan ketepatan model perlu dilakukan pengujian atas beberapa asumsi klasik yang mendasari model regresi yang diantaranya adalah uji normalitas, uji multikolinearitas dan uji heteroskedastisitas. Untuk megetahui apakah maisng-masing variabel bebas (lifestyle, efek komunitas dan fitur produk) berpengaruh terhadap variabel terikat (brand switching) dengan menggunakan hipotesis uji t (uji pengaruh secara parsial/ Individu) dan uji F (uji pengaruh secara stimultan / bersama-sama) serta koefisien determinasi (R2) digunakan untuk mengukur seberapa jauh kemampuan model dalam menerangkan variasi variabel dependen.

\begin{tabular}{|c|c|c|c|c|}
\hline No & $\begin{array}{c}\text { Karakteristik } \\
\text { Responden }\end{array}$ & Klasifikasi & $\begin{array}{l}\text { Jumlah } \\
\text { (Orang) }\end{array}$ & $\begin{array}{c}\text { Persentase } \\
(\%)\end{array}$ \\
\hline \multirow[t]{6}{*}{1} & Umur & $18-24$ Tahun & 99 & 97,05 \\
\hline & & $\geq 25-34$ Tahun & 3 & 2,95 \\
\hline & & $\geq 35-44$ Tahun & & \\
\hline & & $\geq 45-54$ Tahun & & \\
\hline & & $\geq 55$ Tahun ke atas & & \\
\hline & & Total & 102 & 100 \\
\hline \multirow[t]{3}{*}{2} & Jenis Kelamin & Laki-Laki & 93 & 91,17 \\
\hline & & Perempuan & 9 & 8,83 \\
\hline & & Total & 102 & 100 \\
\hline \multirow[t]{5}{*}{3} & Pendidikan & SMA & 75 & 73,5 \\
\hline & Terakhir & & & \\
\hline & & Diploma & 3 & 2,9 \\
\hline & & Sarjana & 24 & 23,5 \\
\hline & & Total & 102 & 100 \\
\hline \multirow[t]{2}{*}{4} & Jenis Pekerjaan & Wiraswasta & 6 & 5,8 \\
\hline & & Pegawai Negeri & 3 & 2,9 \\
\hline
\end{tabular}

\section{Hasil dan Pembahasan}

Hasil penelitian yang dilakukan terhadap masyarakat Kota Denpasar, dapat diketahui gambaran tentang karakteristik responden yang meliputi empat aspek yaitu umur, jenis kelamin, pendidikan terakhir dan pekerjaan.

\section{Tabel 3}

Karakteristik Responden 
INOBIS: Jurnal Inovasi Bisnis dan Manajemen Indonesia Volume 1, Nomor 2, Maret 2018

Tegowati; Nenny Syahrenny; Wininatin Khamimah; Mega Arisia Dewi

$\begin{array}{lcc}\text { Pegawai Swasta } & 6 & 5,8 \\ \text { Pelajar/Mahasiswa } & 87 & 85,2 \\ \text { Ibu Rumah Tangga } & & \\ \begin{array}{l}\text { ABRI / POLRI } \\ \text { Total }\end{array} & \mathbf{1 0 2} & \mathbf{1 0 0}\end{array}$

Sumber: Data diolah, 2018

Tabel 3 menunjukkan bahwa responden berusia 18 - 24 tahun mendominasi terhadap penggunaan Wifi id corner, mengingat pada usia tersebut mereka sangat mengerti tentang internet. Persentase responden laki-laki sebesar 91,17 persen sedangkan perempuan sebesar 8,83 persen. Hal ini berarti laki-laki mendominasi terhadap peralihan warung internet ke Wifi id corner. Kemudian sebagian besar responden memiliki tingkat pendidikan SMA sebesar 73,5 persen, sedangkan responden dengan persentase terkecil berpendidikan Diploma yaitu sebesar 2,9 persen. Ini menyatakan bahwa masyarakat Kota Denpasar berdasarkan pendidikan sebagian besar yang berinternet di Wifi id corner berpendidikan SMA, mengingat pada rentang usia ini mereka ingin mengakses internet dengan lebih leluasa dan selalu mengikuti perkembangan zaman dan yang terakhir sebagian besar responden memiliki pekerjaan sebagai pelajar / mahasiswa, yaitu sebesar 85,2 persen.

Hasil uji validitas menunjukkan bahwa masing masing variabel penelitian valid untuk digunakan yang dapat dilihat pada Tabel 4.

Tabel 4

Rangkuman Hasil Uji Validitas

\begin{tabular}{ccccc}
\hline No & Variabel & Indikator & Korelasi & Keterangan \\
\hline 1 & Lifestyle $\left(\mathrm{X}_{1}\right)$ & $\mathrm{X} 1.1$ & 0,805 & Valid \\
& $\mathrm{X} 1.2$ & 0,880 & Valid \\
& $\mathrm{X} 1.3$ & 0,894 & Valid \\
& & $\mathrm{X} 1.4$ & 0,881 & Valid \\
& & $\mathrm{X} 2.1$ & 0,726 & Valid \\
& Efek Komunitas $\left(\mathrm{X}_{2}\right)$ & $\mathrm{X} 2.2$ & 0,827 & Valid \\
& $\mathrm{X} 2.3$ & 0,829 & Valid \\
& & $\mathrm{X} 2.4$ & 0,897 & Valid \\
& Fitur Produk $\left(\mathrm{X}_{3}\right)$ & $\mathrm{X} 3.1$ & 0,899 & Valid \\
& & $\mathrm{X} 3.2$ & 0,773 & Valid \\
& $\mathrm{X} 3.3$ & 0,936 & Valid \\
& $\mathrm{X} 3.4$ & 0,878 & Valid \\
& & $\mathrm{Y} 1$ & 0,828 & Valid \\
& & $\mathrm{Y} 2$ & 0,856 & Valid \\
& & $\mathrm{Y} 3$ & 0,892 & Valid \\
& & $\mathrm{Y} 4$ & 0,844 & Valid \\
& & $\mathrm{Y} 5$ & 0,837 & Valid \\
\hline
\end{tabular}

Sumber: Data diolah, 2018

Nilai suatu instrument dikatakan reliabel bila nilai Alpha Crombach $\geq 0,6$. Hasil uji reliabilitas dapat dilihat pada Tabel 5 
INOBIS: Jurnal Inovasi Bisnis dan Manajemen Indonesia

Volume 1, Nomor 2, Maret 2018

Tegowati; Nenny Syahrenny; Wininatin Khamimah; Mega Arisia Dewi

Tabel 5

Hasil Uji Reliabilitas

\begin{tabular}{clcc}
\hline No & \multicolumn{1}{c}{ Variabel } & $\begin{array}{c}\text { Cronbach's } \\
\text { Alpha }\end{array}$ & Keterangan \\
\hline 1 & Lifestyle $\left(\mathrm{X}_{1}\right)$ & 0,888 & Reliabel \\
2 & Efek Komunitas $\left(\mathrm{X}_{2}\right)$ & 0,826 & Reliabel \\
3 & Fitur Produk $\left(\mathrm{X}_{3}\right)$ & 0,895 & Reliabel \\
4 & Brand Switching $(\mathrm{Y})$ & 0,896 & Reliabel \\
\hline
\end{tabular}

Sumber : Data diolah, 2018

Tabel 4.6 menjelaskan bahwa nilai Cronbach's Alpha untuk masing-masing variabel > 0,6 ini berarti alat ukur tersebut digunakan kembali untuk meneliti obyek yang sama.

Analisis regresi linier berganda bertujuan untuk mengetahui ketergantungan suatu variabel terikat dengan satu atau lebih variabel bebas. Analisis ini juga dapat menduga arah dari hubugan tersebut serta mengukur derajat keeratan hubungan antara satu variabel terikat dengan satu variabel bebas. Hasil analisis regresi dengan program Statitical Pacage of Social Science (SPSS) versi 15.0 for Windows dapat dilihat pada Tabel 6.

Tabel 6

Rangkuman hasil Analisis Regresi Linier Berganda

\begin{tabular}{lccccc}
\hline & \multicolumn{5}{c}{ Koefisien } \\
& Variabel & \multicolumn{2}{c}{ Regresi } & & \\
& & B & Std. & T & Sig \\
& & 0,606 & 0,984 & 0,616 & 0,539 \\
& & 0,657 & 0,061 & 10,698 & 0 \\
(constant) & & 0,221 & 0,077 & 2,879 & 0 \\
Lifestyle & & 0,354 & 0,067 & 5,245 & 0 \\
Efek Komunitas & $:$ Brand Switching & & & & \\
Fitur Produk & $: 151,492$ & & & & \\
\hline Dependen variable & $: 0,000$ & & & & \\
F Statistik & $: 0,823$ & & & & \\
Sig F & $: 0,817$ & & & &
\end{tabular}

Tabel 6 mendeskripsikan persamaan regresi linier berganda sebagai berikut.

Keterangan .

$$
Y=0,606+0,657 \times 1+0,221 \times 2+0,354 \times 3
$$

$\mathrm{Y}=$ Brand Switching

$\mathrm{X} 1=$ Lifestyle

$\mathrm{X} 2=$ Efek Komunitas

X3 = Fitur Produk 
INOBIS: Jurnal Inovasi Bisnis dan Manajemen Indonesia

Volume 1, Nomor 2, Maret 2018

Tegowati; Nenny Syahrenny; Wininatin Khamimah; Mega Arisia Dewi

Persamaan regresi linier berganda tersebut menunjukkan arah masing-masing variabel bebas terhadap variabel terikatnya. Persamaan regresi linier berganda tersebut dapat diuraikan sebagai berikut.

$\beta 1=+0,657$, berarti apabila variabel lifestyle (X1) mengikat, maka akan mengakibatkan perubahan yang positif pada brand switching (Y), dengan asumsi variabel bebas dianggap konstan.

$\beta 2=+0,221$, berarti apabila variabel efek komunitas (X2) mengikat, maka akan mengakibatkan perubahan yang positif pada brand switching (Y), dengan asumsi variabel bebas dianggap konstan.

$\beta 3=+0,354$, berarti apabila variabel fitur produk (X3) mengikat, maka akan mengakibatkan perubahan yang positif pada brand switching (Y), dengan asumsi variabel bebas dianggap konstan.

$\mathrm{R} 2=0,823$, yang berarti brand switching dipengaruhi oleh variabel lifestyle, efek komunitas, dan fitur produk sebesar $82,3 \%$. Sisanya $17,7 \%$ dipengaruhi variabel lain

Uji normalitas akan ditampilkan pada tabel 7 hasil yang didapatkan dengan menggunakan uji Kolmogorov-Smirnov dengan signifikansi lebih besar dari 0,05 yaitu 0,811 maka dapat disimpulkan bahwa model regresi terdistribusi secara normal.

\section{Tabel 7}

\section{Hasil Uji Kolmogorov-Smirnov}

One-Sample Kolmogorov-Smirnov Test

\begin{tabular}{|ll|r|}
\hline & & $\begin{array}{r}\text { Unstandardiz } \\
\text { ed Residual }\end{array}$ \\
\hline $\mathrm{N}$ & & 102 \\
Normal Parametersa,b & Mean & .0000000 \\
& Std. Deviation & 1.50264564 \\
Most Extreme & Absolute & .063 \\
Differences & Positive & .059 \\
& Negative & -.063 \\
Kolmogorov-Smirnov Z & .638 \\
Asymp. Sig. (2-tailed) & .811 \\
\hline \multicolumn{2}{|c|}{ a. Test distribution is Normal. } \\
b. Calculated from data.
\end{tabular}

Sumber : Data diolah, 2018

Berdasarkan hasil pengujian multikolinearitas dapat diperoleh hasil sebagai berikut pada Tabel 8 .

Tabel 8

Hasil Uji Multikolinearitas

\begin{tabular}{clccc}
\hline \multirow{2}{*}{ No } & \multirow{2}{*}{ Model } & \multicolumn{2}{c}{ Collinearity Statistic } \\
& & Tolerance & VIF \\
\hline 1 & Lifestyle & 0,619 & 1,615 \\
2 & Efek Komunitas & 0,576 & 1,735 \\
3 & Fitur Produk & 0,524 & 1,910 \\
\hline
\end{tabular}

Sumber : Data diolah, 2018 
INOBIS: Jurnal Inovasi Bisnis dan Manajemen Indonesia

Volume 1, Nomor 2, Maret 2018

Tegowati; Nenny Syahrenny; Wininatin Khamimah; Mega Arisia Dewi

Berdasarkan Tabel 8 dapat diketahui nilai VIF (Varian Inflatation Factor) tidak lebih dari 10 dan mempunyai angka tolerance tidak kurang dari 0,1 , maka ini berarti dalam model regresi tidak terjadi multikolinearitas

Tabel 9

Hasil Uji Heteroskedastisitas

\begin{tabular}{cccc}
\hline No & Model & T & Sig \\
\hline 1 & Lifestyle & $-1,223$ & 0,224 \\
2 & Efek Komunitas & $-0,628$ & 0,532 \\
3 & Fitur Produk & 0,850 & 0,397 \\
\hline
\end{tabular}

Sumber : Data diolah, 2018

Berdasarkan Tabel 9 dapat dilihat bahwa variabel Lifestyle memiliki nilai sig. 0,224 > 0,05, variabel Efek Komunitas memiliki nilai sig. 0,532 >0,05, variabel Fitur Produk memiliki nilai sig. 0,397 >0,05 ini berarti pada model regresi tidak terjadi gejala heteroskedasitisitas.

Uji $\mathrm{F}$ dilakukan dengan membandingkan nilai Fhitung dengan nilai Ftabel pada taraf signifikansi 0,05 .

Tabel 10

Hasil Uji F

ANOV A

\begin{tabular}{|c|c|c|c|c|c|c|}
\hline & & $\begin{array}{l}\text { Sum of } \\
\text { Squares }\end{array}$ & df & Mean Square & $\mathrm{F}$ & Sig. \\
\hline \multirow[t]{3}{*}{1} & Regression & 1057.595 & 3 & 352.532 & 151.492 & $.000^{\mathrm{a}}$ \\
\hline & Residual & 228.052 & 98 & 2.327 & & \\
\hline & Total & 1285.647 & 101 & & & \\
\hline
\end{tabular}

a. Predictors: (Constant), Fitur produk, Lifestyle, Efek komunitas

b. Dependent Variable: Brand switching

Sumber : Data diolah, 2018

Berdasarkan Tabel 10 dapat diketahui bahwa Fhitung = 151,492 dan nilai Ftabel dengan tingkat keyakinan 95\% dan $\alpha=0,05 ; \mathrm{df}=(\mathrm{k}-1):(\mathrm{n}-\mathrm{k})=(3: 98)$ adalah sebesar 2,697. Oleh karena Fhitung $(151,492)$ lebih besar dari Ftabel $(2,70)$ dengan nilai signifikansi $0,000<0,05$ maka dapat disimpulkan bahwa lifestyle, efek komunitas dan fitur produk secara simultan berpengaruh terhadap keputusan brand switching warnet ke Wifi id corner di Kota Denpasar. Hal ini berarti model dapat digunakan untuk analisa lebih lanjut atau dengan kata lain model dapat digunakan untuk mempresentasikan karena hasil goodness of fit-nya baik.

Uji t dilakukan dengan membandingkan nilai thitung dengan ttabel pada taraf signifikansi 0,05 dengan pengujian $\alpha=0,05$; $d f=98$, sehingga ttabel $(0,05: 98)$ adalah sebesar 1,661(lampiran 9). Hasil analisis uji t dapat dilihat pada Tabel 11 
INOBIS: Jurnal Inovasi Bisnis dan Manajemen Indonesia

Volume 1, Nomor 2, Maret 2018

Tegowati; Nenny Syahrenny; Wininatin Khamimah; Mega Arisia Dewi

Tabel 11

Hasil Analisis Uji t

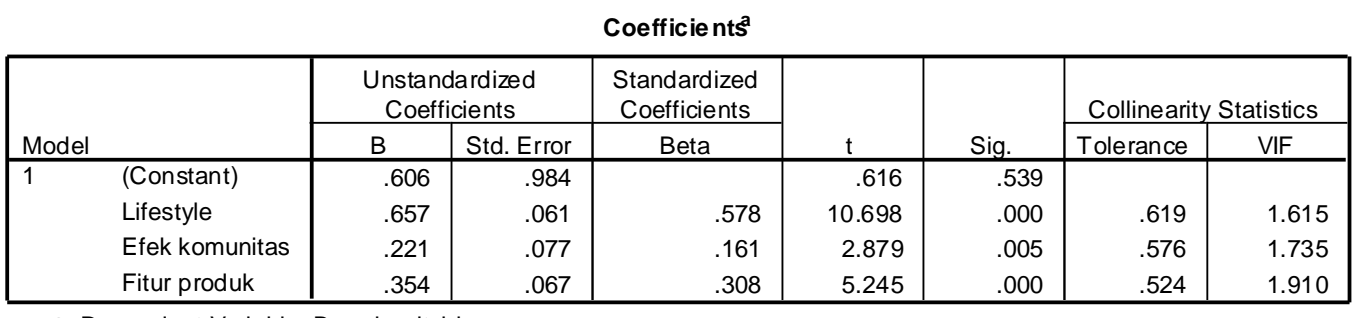

a. Dependent Variable: Brand switching

\section{Sumber : Lampiran 5}

Hipotesis yang menyatakan bahwa lifestyle berpengaruh terhadap brand switching. Tabel 11 menunjukkan nilai signifikan lifestyle (X1) lebih kecil dari 0,05 maka H0 ditolak dan nilai thitung $=10,698$ lebih besar dari ttabel $=1,661$ maka H0 ditolak, ini berarti lifestyle berpengaruh positif terhadap brand switching warnet ke Wifi id corner di Kota Denpasar. Hipotesis yang menyatakan bahwa efek komunitas berpengaruh terhadap brand switching. Tabel 11 menunjukkan nilai signifikan efek komunitas (X2) lebih besar dari 0,05 maka H0 ditolak dan nilai thitung $=2,879$ lebih besar dari ttabel $=1,661$ maka $\mathrm{H} 0$ ditolak, ini berarti efek komunitas berpengaruh signifikan positif terhadap brand switching warnet ke Wifi id corner di Kota Denpasar serta hipotesis yang menyatakan bahwa fitur produk berpengaruh terhadap brand switching. Tabel 11 menunjukkan bahwa nilai signifikansi persepsi kualitas (X3) lebih kecil dari 0,05 maka H0 ditolak dan nilai thitung = 5,245 lebih besar dari ttabel = 1,661 maka H0 ditolak, ini berarti fitur produk berpengaruh positif signifikan terhadap brand switching warnet ke Wifi id corner di Kota Denpasar.

\section{Kesimpulan}

Simpulan dari penelitian ini berdasarkan pada pembahasan pada bab-bab sebelumnya, adalah Lifestyle berpengaruh positif dan signifikan terhadap keputusan brand switching warung internet ke Wifi id corner di Kota Denpasar, dengan nilai thitung = 10,698 lebih besar dari ttabel $=1,661$. Efek Komunitas berpengaruh positif dan signifikan terhadap keputusan brand switching warung internet ke Wifi id corner di Kota Denpasar, dengan nilai thitung $=2,879$ lebih besar dari ttabel $=1,661$. Fitur Produk berpengaruh positif dan signifikan terhadap keputusan brand switching warung internet ke Wifi id corner di Kota Denpasar, dengan nilai thitung = 5,245 lebih besar dari ttabel $=1,661$.

Saran dari penelitian ini berdasarkan kesimpulan di atas yang dapat diberikan kepada pihak yang memerlukan adalah Wifi id corner di Denpasar harus tetap menjaga kulaitasnya sehingga pelanngan nyaman dalam beraktifias serta menjaga minat pelanggan dalam mengakses internet agar tidak berpindah menggunakan akses lain selain itu wifi id corner di Kota Denpasar harus bisa menjaga hubungan yang baik kepada indvidu ataupun kelompok yang ber-internet terutama kepada pelanggan yang membawa anggota keluarga dalam mengakses internet sehingga mendapatkan citra yang baik dan diharapkan dapat menarik lebih banyak pelanggan. Wifi id corner di Kota Denpasar juga diharapkan memberikan fitur yang lebih beragam dan sesuai harapan pelanggan sehingga mereka puas dan tidak berminat untuk beralih tempat untuk ber- 
INOBIS: Jurnal Inovasi Bisnis dan Manajemen Indonesia

Volume 1, Nomor 2, Maret 2018

Tegowati; Nenny Syahrenny; Wininatin Khamimah; Mega Arisia Dewi

internet. Bagi peneliti selanjutnya dimasa mendatang hendaknya memperhatikan dan mengembangkan faktor-faktor lain yang dapat mempengaruhi brand switching selain ataupun dari lifestyle, efek komunitas dan fitur produk agar kedepannya pengusaha apapun minimal dapat mempertahankan produknya dari pesaing.

\section{Daftar Pustaka}

Alana, Aditya Yessika., Hidayat, Wahyu., Handoyo, Joko W. 2013. Pengaruh Citra Merek, Desain, dan Fitur Produk terhadap Keputusan Pembelian Handphone Nokia (Studi Kasus pada Mahasiswa Universitas Diponegoro). Jurnal Ilmu Administrasi Bisnis, 2(2), hal.6977.

Carpenter, GS. 2012. “Handbook Of Marketing Strategy”, Edward Elgar Publishing Ltd.

Firdaus, Muhammad Irfan dan Rahardjo, Mudji. 2015. Analisis Pengaruh Harga, Kebutuhan Mencari Variasi, Dan Word Of Mouth Dalam Perilaku Brand Switching Pada Minuman Bersoda Coca-Cola Ke Big Cola. Diponegoro Journal Of Management, 4(1), hal.1-14

Hamidah, Siti dan Anita, Desi. 2013. Analisis Persepsi Citra Merek, Desain, Fitur Dan Pengaruhnya Terhadap Keputusan Pembelian Produk Handphone Samsung Berbasis Android (Studi Kasus STIE Pelita Indonesia). Jurnal Ekonomi, 21(4), hal.1-20

Kertajaya, Hermawan, 2010, Marketing Plus 2000, Siasat Memenangkan Persaingan Global. Jakarta :PT. Gramedia Pustaka Utama.

Kotler. P dan Kevin. L. Keller. 2008. Manajemen Pemasaran. Jakarta: Indeks Gramedia.

Krisnadewi, Komang Ayu. 2010. Pergeseran Peran Akuntansi Manajemen Pada Era Globalisasi. Jurnal Ilmiah Akuntansi dan Bisnis, 5(2), hal.1-18

Marbun, Merliati., Yona, Mira., Ariyati, Yannik. 2016. Pengaruh Promosi Dan Kualitas Produk Terhadap Volume Penjualan Pada Pt Cipta Group Kota Batam (Studi Kasus Pada Perumahan Buana Bukit Permata Di Batam).beningjournal, 3(2), hal.1-10

Mardiastika, Ema. 2012. Analisis Pengaruh Kualitas Layanan, Kualitas Film, Efek Komunitas Dan Persepsi Harga Terhadap Sikap Menonton Dan Implikasinya Terhadap Minat Menonton. Skripsi. Fakultas Ekonomika Dan Bisnis Universitas Diponegoro.

Prihastono, Endro. 2010. Pemanfaatan Teknologi Internet Dalam Bisnis Suatu Perusahaan ECommerce. Dinamika Teknik, 4(2), hal.1-12

Ramadhani, Aditia Fakhri. 2013. Analisis Pengaruh Promosi, Efek Komunitas, Reputasi Perusahaan, Harga, Dan Kompetensi Tenaga Marketing Terhadap Minat Konsumen Mengambil Kredit Di PT BPR Weleri Makmur Semarang. Jurnal Sains Pemasaran Indonesia, 12(1), hal.1-25

Rapala, Anna. 2014. Elements Of Brand Loyalty In Lifestyle Brand Context. Thesis. Aalto University School Of Business

Saeed, Munazza dan Azmi, Ilhaamie Binti Abdul Ghani. 2014. Religion and Brand Switching Behavior of Muslim Consumers. Middle-East Journal of Scientific Research, 21 (9), pp.1611-1617

Susanto, Dwi. 2011. Analisis Pengaruh Efek Komunitas Dan Kualitas Produk Terhadap Kepuasan Konsumen Dan Implikasinya Terhadap Sikap Terhadap Merek (Attitudes Toward Brand) Pada Konsumen Notebook Merek Acer Di Kota Semarang. Skripsi. Universitas Diponegoro.

Usmara. 2003. Strategi Baru Manajemen Pemasaran. Asmara Books, Yogyakarta. 
INOBIS: Jurnal Inovasi Bisnis dan Manajemen Indonesia

Volume 1, Nomor 2, Maret 2018

Tegowati; Nenny Syahrenny; Wininatin Khamimah; Mega Arisia Dewi

Utama, Made Suyana. 2011. Aplikasi Analisis Kuantitatif. Edisi Kelima. Diktat kuliah pada Fakultas Ekonomi dan Bisnis Universitas Udayana

Wibowo, Aan Tri. 2013. Pembuatan Aplikasi E-Commerce Pusat Oleh-Oleh Khas Pacitan Pada Toko Sari Rasa Pacitan. Indonesian Journal on Networking and Security, 2(4), hal.1-6.

Wirtz, Jochen et al. 2013. Managing Brands And Customer Engagement In Online Brand Communities. Journal of Service Management, 24(3), pp.223-244.

Yuliana, Oviliani Yenty. 2000. Penggunaan Teknologi Internet dalam Bisnis. Jurnal Akuntansi \& Keuangan, 2(1), hal.36-52. 